\title{
Profil Penatalaksanaan Kanker Serviks Stadium IIB-IIIB dengan Terapi Radiasi dan Kemoradiasi di Rumah Sakit Umum Pusat Dr. Hasan Sadikin Bandung Periode Tahun 2015-2017
}

\author{
Dewi Legianawati ${ }^{1}$, Irma M. Puspitasari ${ }^{1,2}$, Auliya A. Suwantika ${ }^{1,2}$, Adji Kusumadjati ${ }^{3}$ \\ ${ }^{1}$ Magister Farmasi Klinik, Fakultas Farmasi, Universitas Padjadjaran, Sumedang, Indonesia, \\ ${ }_{2}^{2}$ Pusat Unggulan Iptek Perguruan Tinggi Inovasi Pelayanan Kefarmasian, Universitas \\ Padjadjaran, Sumedang, Indonesia, ${ }_{3}^{3}$ Instalasi Onkologi Radiasi Rumah Sakit \\ Umum Pusat Dr. Hasan Sadikin, Bandung, Indonesia
}

\begin{abstract}
Abstrak
Kanker serviks merupakan jenis kanker dengan kasus kedua terbanyak di Rumah Sakit Umum Pusat Dr. Hasan Sadikin (RSHS) dan $82 \%$ di antaranya merupakan stadium II dan III. Terapi yang direkomendasikan untuk kanker serviks stadium IIB-IIIB menurut Pedoman Nasional Pelayanan Kedokteran (PNPK) kanker serviks adalah kemoradiasi atau radioterapi. Tujuan penelitian ini adalah untuk memberikan gambaran profil penatalaksanaan kanker serviks stadium IIB-IIIB dengan radioterapi dan kemoradiasi di RSHS pada tahun 2015-2017. Penelitian ini merupakan penelitian observasional dengan metode potong lintang. Pengambilan data dilakukan secara retrospektif dari rekam medik pasien di Instalasi Onkologi Radiasi dan Sistem Informasi Rumah Sakit (SIRS) RSHS dengan kriteria inklusi pasien dewasa berusia lebih dari 18 tahun, memiliki data klinis dan data terapi yang lengkap serta tidak memiliki penyakit penyerta. Data yang diperoleh dianalisis secara deskriptif dan secara statistik dengan uji Kruskal Wallis untuk data numerik serta uji Chi-Square dan uji Fisher's Exact untuk data kategorik. Terdapat 234 data pasien yang memenuhi kriteria. Sebanyak 94,01\% pasien berasal dari Jawa Barat, $86,1 \%$ merupakan ibu rumah tangga dan $63,6 \%$ mengenyam pendidikan hingga tingkat Sekolah Dasar. Radioterapi merupakan terapi yang lebih banyak diberikan kepada pasien dengan dosis total sekitar 6700-7200cGy dan ratarata lama terapi selama 14 minggu. Rata-rata waktu yang diperlukan pasien untuk mendapatkan terapi setelah mendaftar untuk terapi sekitar 7 minggu. Regimen kemoterapi sisplatin merupakan regimen pilihan utama yang diberikan pada pasien dengan kemoradiasi dengan frekuensi 1-5 kali pemberian. Efek samping yang paling sering terjadi pada terapi kanker serviks baik dengan radioterapi maupun kemoradiasi adalah mual dan muntah. Analisis efektivitas biaya akan dilakukan pada penelitian selanjutnya untuk mengetahui terapi mana yang lebih baik dari segi efektivitas terapi dan biaya.
\end{abstract}

Kata kunci: Kanker serviks, kemoradiasi, radioterapi, stadium IIB-IIIB, tatalaksana kanker serviks

\section{Management Profile of Stage IIB-IIIB Cervical Cancer with Radiation Therapy and Chemoradiation at Dr. Hasan Sadikin General Hospital Bandung in 2015-2017}

\begin{abstract}
Cervical cancer is a type of cancer with the second most cases at Dr. Hasan Sadikin General Hospital (RSHS) Bandung and $82 \%$ of those cases are stage II and III. Recommended therapy for cervical cancer stage IIBIIIB according to the National Medical Services guidelines for cervical cancer (PNPK) is chemoradiation or radiotherapy. The purpose of this study was to provide an overview of the management profile of stage IIB-IIIB cervical cancer with radiotherapy and chemoradiation at RSHS in 2015-2017. This study was an observational study with a cross-sectional method. Retrospective data collection was carried out from medical records of patients in Radiation Oncology Installation and Hospital Information System (SIRS) with inclusion criteria of adult patient with over 18 years of age, having complete clinical and therapeutic data and not having any comorbidities. Obtained data were analyzed descriptively and statistically with Kruskal Wallis test for numerical data and Chi-Square test and Fisher's Exact test for categorical data. A total of 234 patients' data met the criteria. Ninety four percent of patients came from West Java, 86.1\% were housewives and $63.6 \%$ had a primary school education level. Most of patients were given radiotherapy with a total dose of about 6700-7200cGy and the average length of therapy was 14 weeks. The average time for a patient to obtain therapy after registering for therapy was about 7 weeks. Cisplatin was the first line chemotherapy regimen given to patients with chemoradiation with a frequency of $1-5$ times administration. The most common side-effects of cervical cancer therapy with radiotherapy or chemoradiation were nausea and vomiting. Cost-effectiveness analysis will be carried out in further research to find out which therapies are better in terms of therapy and cost-effectiveness.
\end{abstract}

Keywords: Cervical cancer, chemoradiation, management of cervical cancer, radiotherapy, stage IIB-IIIB

Korespondensi: Dewi Legianawati, S.Si., Apt., Magister Farmasi Klinik, Fakultas Farmasi, Universitas Padjadjaran, Sumedang, Jawa Barat 45363, Indonesia, e-mail: legianawati@gmail.com

Naskah diterima: 17 Juni 2019, Diterima untuk diterbitkan: 30 Agustus 2019, Diterbitkan: 28 September 2019 


\section{Pendahuluan}

Kanker serviks merupakan jenis kanker yang sering terjadi pada wanita, yaitu pada daerah serviks yang merupakan sepertiga bagian bawah uterus, berbentuk silindris, menonjol serta berhubungan dengan vagina melalui ostium uteri eksternum. ${ }^{1}$ Berdasarkan laporan data GLOBOCAN, proyek dari International Agency for Research on Cancer (IARC), pada tahun 2018 terdapat 18,1 juta kasus baru kanker dan 9,6 juta kematian akibat kanker di seluruh dunia. Dari insiden kanker tersebut, kanker serviks menempati peringkat keempat insidensi kanker pada wanita di dunia setelah kanker payudara, kanker kolorektal dan kanker paru-paru. ${ }^{2}$ Selain itu, berdasarkan estimasi GLOBOCAN tahun 2018, kanker serviks menempati peringkat kedua insidensi kanker dengan 32.469 kasus baru dan menempati peringkat ketiga penyebab kematian akibat kanker dengan 18.729 kematian di Indonesia. ${ }^{2}$ Di Provinsi Jawa Barat, prevalensi kanker serviks mencapai 0,7 per seribu penduduk perempuan. ${ }^{3}$ Pada tahun 2017, terdapat 327 kasus kanker serviks di Rumah Sakit Umum Pusat Dr Hasan Sadikin (RSHS) dan kanker serviks merupakan jenis kanker dengan kasus kedua terbanyak.

Pada hasil penelitian oleh Suwendar et al. (2016), penderita kanker serviks terbanyak di RSHS Bandung adalah stadium lokal lanjut (stadium IIA-IVA), dan $82 \%$ di antaranya merupakan stadium II dan III. ${ }^{4}$ Terapi yang paling umum dilakukan pada kanker serviks antara lain operasi (hysterectomy), radiasi (radiotherapy), kemoterapi, atau kombinasi dari dua atau tiga jenis terapi tersebut. ${ }^{5}$ Berdasarkan Pedoman Nasional Pelayanan Kedokteran (PNPK) Kanker Serviks, terapi yang direkomendasikan untuk stadium IIBIIIB adalah kemoradiasi atau radioterapi. ${ }^{1}$ Pada penelitian ini, akan dipaparkan profil penatalaksanaan kanker serviks stadium IIBIIB yang diberikan terapi kemoradiasi atau radioterapi beserta demografi, karakteristik pasien dan efek samping yang terjadi selama terapi kanker serviks.

\section{Metode}

Penelitian ini merupakan studi observasional dengan metode potong lintang dan merupakan penelitian deskriptif dengan pengambilan data secara retrospektif. Penelitian ini dilakukan pada bulan Februari-April 2019 di Instalasi Rekam Medik, Instalasi Radiasi Onkologi dan Bagian Sistem Informasi Rumah Sakit (SIRS) Rumah Sakit Umum Pusat Dr. Hasan Sadikin (RSHS) Bandung. Persetujuan etik telah diperoleh dari Komisi Etik Penelitian Universitas Padjadjaran dengan nomor 1460/ UN6.KEP/EC/2018.

Sampel penelitian ini adalah data rekam medik pasien dengan diagnosis utama kanker serviks stadium IIB-IIIB (kode ICD10: C53.9) yang memenuhi kriteria inklusi dan eksklusi. Kriteria inklusi pada penelitian ini adalah data pasien kanker serviks stadium IIB-IIIB usia $\geq 18$ tahun yang mendapatkan kedua terapi lengkap yakni kemoradiasi atau radioterapi pada rentang waktu 1 Januari 2015-31 Desember 2017, dengan data klinis data terapi yang lengkap, sedangkan kriteria eksklusi pada penelitian ini antara lain pasien yang memiliki penyakit penyerta hipertensi, jantung, diabetes melitus, dan gagal ginjal. Pengambilan sampel penelitian ini dilakukan secara konsekutif (consecutive sampling).

Jumlah sampel penelitian dihitung dengan menggunakan rumus Slovin, ${ }^{6}$ dengan rincian perhitungan sebagai berikut: populasi pasien kanker serviks di RSHS tahun 2015 adalah 256 pasien, tahun 2016 adalah 26, dan tahun 2017 adalah 327 pasien. Oleh karena itu, jumlah sampel minimal yang diambil pada penelitian ini dengan batas toleransi kesalahan sebesar $10 \%$ adalah 72 pasien untuk tahun 2015, 73 pasien untuk tahun 2016, dan 76 pasien untuk tahun 2017. 
Hasil pengumpulan data pada penelitian ini dianalisis dengan menggunakan perangkat lunak SPSS versi 24. Data demografi pasien, karakteristik pasien, serta efek samping dari terapi dilakukan analisis secara deskriptif. Perbedaan pada data profil penatalaksanaan kanker serviks tahun 2015-2017 dianalisis dengan menggunakan uji Kruskal Wallis untuk data numerik dan tidak terdistribusi normal, uji Chi-Square untuk data kategorik, dan uji Fisher's Exact untuk data kategorik yang tidak memenuhi syarat uji Chi-Square. Perbedaan dinyatakan signifikan jika nilai $\mathrm{p}<0,05$.

\section{Hasil}

Alur proses pengumpulan data dapat dilihat pada Gambar 1. Pada penelitian ini, diperoleh

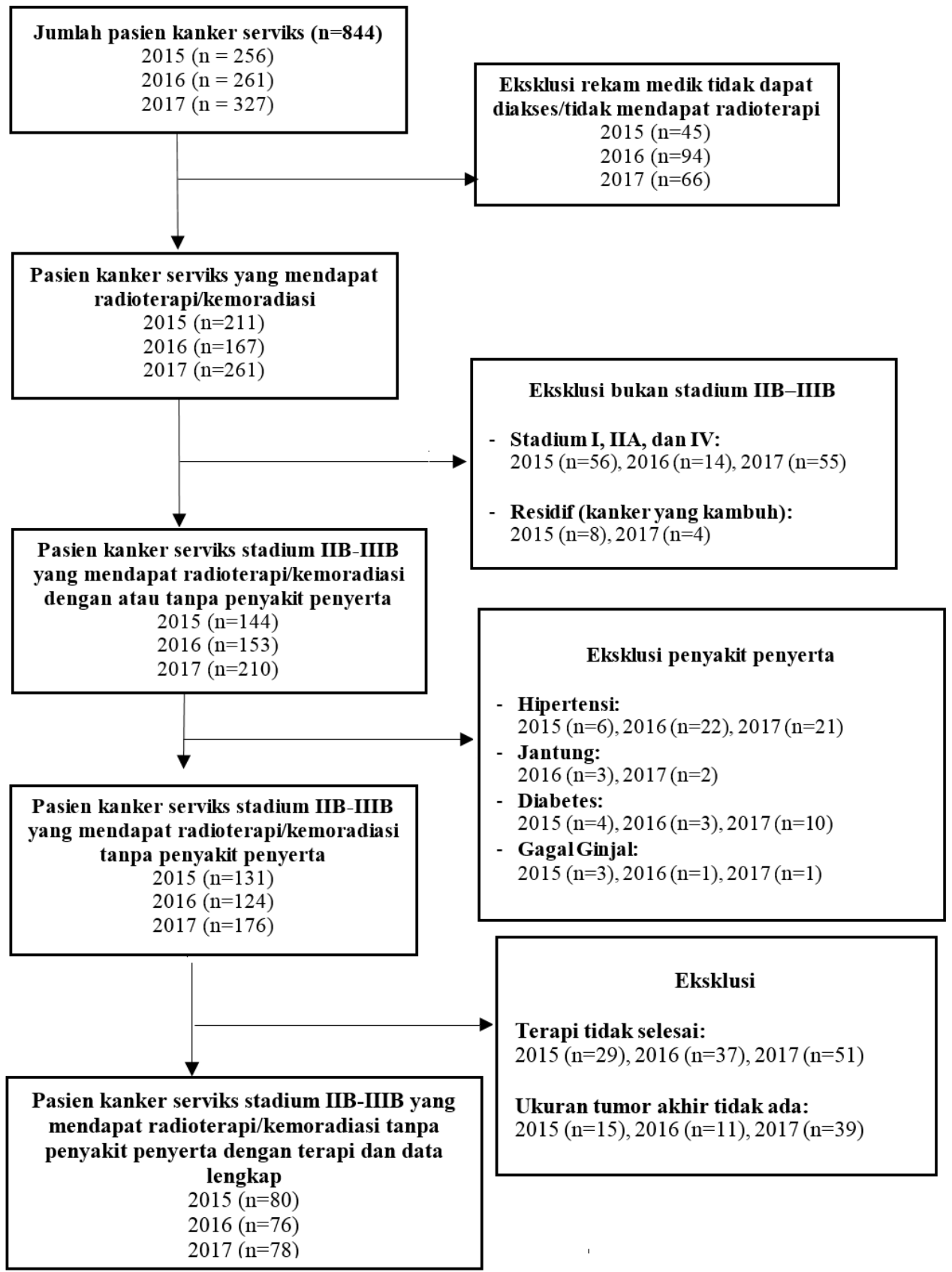

Gambar 1 Proses Pengumpulan Data 
total data rekam medik periode 2015-2017 yakni sebanyak 844 data pasien. Dari jumlah tersebut, rekam medik yang dapat diakses adalah sebanyak 639 rekam medik, dan dari rekam medik yang dapat diakses, dilakukan eksklusi non-stadium IIB-IIIB sebanyak 125 rekam medik, eksklusi penyakit penyerta sebanyak 76 rekam medik, dan eksklusi tidak selesai terapi atau ukuran tumor akhir tidak dicantumkan sebanyak 182 rekam medik, sehingga diperoleh sampel penelitian total 234 data dengan rincian: 80 rekam medik tahun 2015, 76 rekam medik tahun 2016, dan 78 rekam medik tahun 2017.

Data demografi pasien dapat dilihat pada Tabel 1. Pasien kanker serviks dengan rentang usia 42-53 tahun menempati jumlah urutan tertinggi yaitu 149 pasien $(63,6 \%)$. Tingkat pendidikan yang dominan adalah Sekolah Dasar sebanyak 127 pasien (54,3\%), dengan pekerjaan dominan adalah ibu rumah tangga (tidak bekerja) sebanyak 191 pasien (81,6\%), serta mayoritas pasien berasal dari Provinsi Jawa Barat yaitu 220 pasien $(94,01 \%)$.

Tabel 2 menggambarkan data karakteristik pasien terkait menarce (usia pertama kali mendapatkan haid), stadium, tipe histologi, dan gejala awal yang dialami. Usia menarce dengan jumlah terbesar adalah usia 12-14 tahun sebanyak 136 pasien $(58,1 \%)$. Stadium kanker yang diderita oleh pasien pada tahun 2015 dan tahun 2017 dengan jumlah terbesar adalah stadium IIB, sedangkan pada tahun 2016, jumlah terbesar adalah stadium IIIB.

Tabel 1 Data Demografi Pasien

\begin{tabular}{|c|c|c|c|c|c|c|c|c|}
\hline \multirow{2}{*}{ Variabel } & \multicolumn{2}{|c|}{$2015(n=80)$} & \multicolumn{2}{|c|}{$2016(n=76)$} & \multicolumn{2}{|c|}{$2017(n=78)$} & \multicolumn{2}{|c|}{ Total $(n=234)$} \\
\hline & Jumlah & $\%$ & Jumlah & $\%$ & Jumlah & $\%$ & Jumlah & $\%$ \\
\hline \multicolumn{9}{|l|}{ Umur (tahun) } \\
\hline$<40$ & 8 & 10,0 & 5 & 6,6 & 7 & 9,0 & 20 & 8,5 \\
\hline $40-55$ & 54 & 67,5 & 48 & 63,2 & 47 & 60,2 & 149 & 63,7 \\
\hline$>55$ & 18 & 22,5 & 23 & 30,3 & 24 & 30,8 & 65 & 2,8 \\
\hline \multicolumn{9}{|l|}{ Pendidikan } \\
\hline Tidak sekolah & 1 & 1,3 & 1 & 1,3 & 2 & 2,6 & 4 & 1,7 \\
\hline SD & 37 & 46,3 & 48 & 63,2 & 42 & 53,8 & 127 & 54,3 \\
\hline SMP & 19 & 23,8 & 11 & 14,5 & 10 & 12,8 & 40 & 17,1 \\
\hline SMA & 16 & 20,0 & 12 & 15,8 & 18 & 23,1 & 46 & 19,6 \\
\hline D3/S1 & 7 & 8,8 & 4 & 5,3 & 6 & 7,7 & 17 & 7,3 \\
\hline \multicolumn{9}{|l|}{ Pekerjaan } \\
\hline Tidak bekerja & 72 & 90,0 & 58 & 76,3 & 61 & 78,2 & 191 & 81,6 \\
\hline PNS & 3 & 3,8 & 3 & 3,9 & 3 & 3,8 & 9 & 3,8 \\
\hline Pegawai swasta/wiraswasta & 2 & 2,5 & 7 & 9,2 & 7 & 9,0 & 16 & 6,8 \\
\hline Petani/pedagang & 3 & 3,8 & 5 & 6,6 & 3 & 3,9 & 11 & 4,7 \\
\hline Lain-lain & 0 & 0,0 & 3 & 3,9 & 4 & 5,1 & 7 & 3,0 \\
\hline \multicolumn{9}{|l|}{ Asal Kota } \\
\hline Bdg/Cimahi & 17 & 21,3 & 16 & 21,1 & 30 & 38,5 & 63 & 26,9 \\
\hline $\mathrm{Cjr} / \mathrm{Bgr} / \mathrm{Skbm}$ & 12 & 15,0 & 11 & 14,5 & 9 & 11,5 & 32 & 13,7 \\
\hline $\mathrm{Crb} /$ Indrmy & 9 & 11,3 & 11 & 14,5 & 10 & 12,8 & 30 & 12,8 \\
\hline $\mathrm{Kng} / \mathrm{Mjlk} / \mathrm{Smd}$ & 13 & 16,3 & 7 & 9,2 & 8 & 10,3 & 28 & 12,0 \\
\hline $\mathrm{Grt} / \mathrm{Cms} / \mathrm{Tsm}$ & 11 & 13,8 & 11 & 14,5 & 5 & 6,4 & 27 & 11,5 \\
\hline Krw/Pwk/Sbg/Bks & 16 & 20,0 & 14 & 18,4 & 10 & 12,9 & 40 & 17,1 \\
\hline Lain-lain & 2 & 2,5 & 6 & 7,9 & 6 & 7,7 & 14 & 6,0 \\
\hline \multicolumn{9}{|l|}{ Asal Provinsi } \\
\hline Jawa Barat & 78 & 97,5 & 70 & 92,1 & 72 & 92,3 & 220 & 94,0 \\
\hline Luar Jawa Barat & 2 & 2,5 & 6 & 7,9 & 6 & 7,7 & 14 & 6,0 \\
\hline
\end{tabular}


Adapun tipe histologi sel kanker serviks dengan jumlah yang paling tinggi adalah tipe sel skuamosa sebanyak 167 pasien $(71,4 \%)$. Gejala perdarahan per vagina dialami oleh $77,5 \%$ pasien (tahun 2015), 88,2\% pasien (tahun 2016), dan 93,6\% pasien (tahun 2017). Gejala keputihan dialami oleh $86,3 \%$ pasien (tahun 2015), 89,5\% pasien (tahun 2016), dan 70,5\% pasien (tahun 2017). Gejala awal yang paling sering dialami sebanyak dua dan tiga gejala sekaligus, yakni perdarahan dari jalan lahir dan keputihan (dua gejala) dan perdarahan kontak, pendarahan dari jalan lahir dan keputihan (tiga gejala) masingmasing sebanyak 81 pasien (34,6\%).

Profil penatalaksanaan kanker serviks stadium IIB-IIIB di RSHS dapat dilihat pada Tabel 3. Terapi radiasi tanpa kemoterapi (radioterapi) merupakan terapi yang lebih banyak diberikan kepada pasien pada studi ini, yaitu sebanyak 121 pasien (51,7\%). Pada umumnya, waktu yang diperlukan dari saat diagnosis sampai pasien mendaftar untuk terapi adalah 0-4 minggu (47,9\%), namun ada pula yang mendaftar terapi setelah 12 minggu dari saat diagnosis, yakni 52 pasien $(22,2 \%)$. Adapun waktu tunggu yang diperlukan pasien sejak pasien terdaftar sampai terapi pertama pada umumnya sekitar 5-8 minggu, yakni sebanyak 99 pasien $(42,3 \%)$ dengan rata-rata waktu tunggu sekitar 7 minggu. Sebanyak 14 pasien $(6,0 \%)$ menunggu mendapatkan terapi lebih dari 12 minggu. Walaupun demikian, terdapat pengurangan waktu tunggu secara signifikan pada tahun 2016 dan 2017 dari tahun $2015(p=0,000)$. Jenis pesawat yang digunakan untuk radioterapi yang paling sering digunakan adalah Cobalt-60. Pesawat radiasi Cobalt-60 digunakan pada 200 pasien $(85,5 \%)$. Dosis total radiasi yang diberikan kepada pasien adalah sekitar 6700-7200cGy dengan rata-rata lama terapi yaitu selama 14

Tabel 2 Karakteristik Pasien

\begin{tabular}{|c|c|c|c|c|c|c|c|c|}
\hline \multirow{2}{*}{ Variabel } & \multicolumn{2}{|c|}{$2015(n=80)$} & \multicolumn{2}{|c|}{$2016(n=76)$} & \multicolumn{2}{|c|}{$2017(n=78)$} & \multicolumn{2}{|c|}{ Total $(n=234)$} \\
\hline & Jumlah & $\%$ & Jumlah & $\%$ & Jumlah & $\%$ & Jumlah & $\%$ \\
\hline \multicolumn{9}{|l|}{ Usia Menarce (tahun) } \\
\hline $9-11$ & 1 & 1,3 & 2 & 2,6 & 2 & 2,6 & 5 & 2,1 \\
\hline $12-14$ & 51 & 63,8 & 29 & 38,2 & 56 & 71,8 & 136 & 58,1 \\
\hline$>14$ & 25 & 31,2 & 32 & 42,1 & 12 & 15,4 & 69 & 29,5 \\
\hline Tidak ditulis & 3 & 3,7 & 13 & 17,1 & 8 & 10,2 & 24 & 10,3 \\
\hline \multicolumn{9}{|l|}{ Stadium } \\
\hline IIB & 44 & 55,0 & 30 & 39,5 & 42 & 53,8 & 116 & 49,6 \\
\hline IIIA & 1 & 1,3 & 5 & 6,6 & 1 & 1,3 & 7 & 3,0 \\
\hline IIIB & 35 & 43,8 & 41 & 53,9 & 35 & 44,9 & 111 & 47,4 \\
\hline \multicolumn{9}{|l|}{ Tipe Histologi } \\
\hline KSS & 65 & 81,3 & 50 & 65,7 & 52 & 66,7 & 167 & 71,3 \\
\hline Adenokarsinoma & 10 & 12,4 & 11 & 14,5 & 7 & 9,0 & 28 & 11,5 \\
\hline Epidermoid karsinoma & 5 & 6,3 & 9 & 11,8 & 14 & 17,9 & 28 & 11,5 \\
\hline Lain-lain & 0 & 0,0 & 6 & 7,9 & 5 & 6,4 & 11 & 4,7 \\
\hline \multicolumn{9}{|l|}{ Gejala Awal } \\
\hline $\mathrm{PCB}+\mathrm{PPV}+\mathrm{FA}$ & 22 & 27,5 & 32 & 42,1 & 27 & 34,6 & 81 & 34,6 \\
\hline $\mathrm{PCB}+\mathrm{PPV}$ & 2 & 2,5 & 4 & 5,3 & 7 & 9,0 & 13 & 5,6 \\
\hline $\mathrm{PCB}+\mathrm{FA}$ & 15 & 18,8 & 6 & 7,9 & 2 & 2,6 & 23 & 9,8 \\
\hline $\mathrm{PPV}+\mathrm{FA}$ & 29 & 36,3 & 28 & 36,8 & 24 & 30,8 & 81 & 34,6 \\
\hline PCB saja & 0 & 0,0 & 1 & 1,3 & 1 & 1,3 & 2 & 0,9 \\
\hline PPV saja & 8 & 10,0 & 3 & 3,9 & 15 & 19,2 & 26 & 11,1 \\
\hline FA saja & 4 & 5,0 & 2 & 2,6 & 2 & 2,6 & 8 & 3,4 \\
\hline
\end{tabular}


Tabel 3 Profil Penatalaksanaan Kanker Serviks

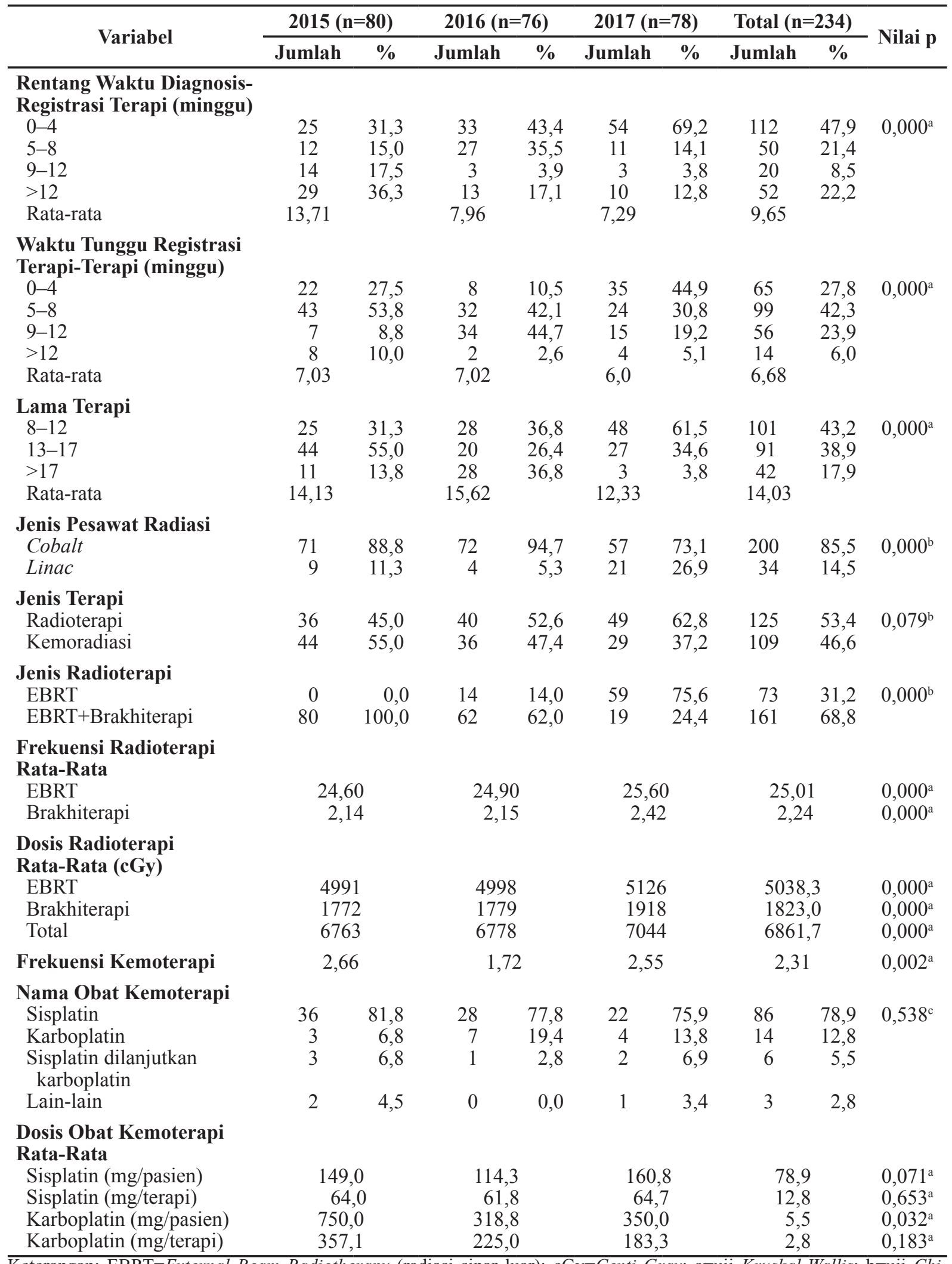

Keterangan: EBRT=External Beam Radiotherapy (radiasi sinar luar); cGy=Centi Gray; a=uji Kruskal-Wallis; b=uji ChiSquare; c=uji Fisher's Exact; $\mathrm{p}<0,05=$ terdapat perbedaan signifikan antara tahun 2015, 2016, dan 2017; $>00,05=$ tidak terdapat perbedaan signifkan antara tahun 2015, 2016, dan 2017 
minggu. Terdapat pengurangan lama terapi secara signifikan pada tahun 2016 dan 2017 terhadap tahun $2015(\mathrm{p}=0,000)$. Frekuensi dari pemberian kemoterapi yakni sebanyak 1-5 kali pemberian selama terapi dengan ratarata 1,72-2,66 kali menggunakan regimen kemoterapi sisplatin. Rata-rata dosis total sisplatin untuk masing-masing pasien adalah $149 \mathrm{mg}$ (tahun 2015), 114,3 mg (tahun 2016), dan $160 \mathrm{mg}$ (tahun 2017), sedangkan dosis sisplatin yang diberikan setiap kali pemberian kemoterapi adalah $64 \mathrm{mg}$ (tahun 2015), 61,8 mg (tahun 2016), dan 64,7 mg (tahun 2017).

Selama menjalani terapi, pasien mengalami beberapa efek samping seperti mual, muntah, diare, sakit buang air kecil, sakit buang air besar, lecet dan gatal. Jenis efek samping yang terjadi dapat dilihat pada Tabel 4. Jenis efek samping yang paling sering terjadi pada terapi kanker serviks, baik terapi dengan kemoradiasi maupun radioterapi saja, adalah mual (86 laporan) dan diare (64 laporan). Jumlah kejadian efek samping pada pasien kemoradiasi lebih banyak dibandingkan pada pasien yang diterapi dengan radioterapi saja, yaitu $89 \%$ pada kemoradiasi dan $77,6 \%$ pada radioterapi.

\section{Pembahasan}

Hasil penelitian ini menggambarkan profil penatalaksanaan kanker serviks stadium IIBIIB dengan terapi radiasi dan kemoradiasi di RSHS periode 2015-2017 yang meliputi demografi pasien, karakteristik, jenis terapi, regimen kemoterapi yang diberikan dan efek samping yang terjadi. Berdasarkan data demografi pasien, tingkat pendidikan dengan jumlah terbesar pada penderita kanker serviks adalah Sekolah Dasar. Hasil penelitian ini mendukung hasil dari penelitian sebelumnya, yaitu penelitian yang dilakukan oleh Sharma dan Patthansetthy (2017) di India bahwa sebanyak $46,5 \%$ penderita kanker serviks mempunyai tingkat pendidikan rendah atau tidak berpendidikan. ${ }^{7}$ Penelitian oleh Reis et al. (2011) juga menunjukkan hasil serupa; dari hasil penelitian tersebut ditemukan bahwa jumlah terbesar penderita kanker serviks adalah pasien dengan pendidikan rendah (49,8\%). ${ }^{8}$ Penelitian oleh Francheschi et al. (2019) menyatakan bahwa tingkat pendidikan merupakan faktor risiko terjadinya kanker serviks. ${ }^{9}$ Hal ini mungkin disebabkan oleh rendahnya pengetahuan mengenai penyakit kanker serviks. ${ }^{10}$ Seseorang dengan tingkat pendidikan rendah cenderung untuk menikah dini sehingga hubungan seksual pertama kali terjadi pada usia muda. ${ }^{11}$ Berdasarkan penelitian Reis et al. (2011), ditemukan bahwa hubungan seksual pertama yang terjadi pada usia yang terlalu muda merupakan faktor risiko terjadinya kanker serviks. ${ }^{8}$

Lebih dari $81 \%$ penderita kanker serviks pada penelitian ini merupakan ibu rumah tangga dan tidak bekerja, sejalan dengan hasil penelitian yang dilakukan Chandrawati (2016) bahwa pekerjaan merupakan faktor risiko terjadinya kanker serviks. ${ }^{12}$ Hal ini kemungkinan disebabkan wanita yang tidak bekerja kurang mendapatkan akses terhadap informasi tentang kanker serviks, baik tentang hygiene vagina, tanda/gejala awal maupun terapinya.

Stadium kanker terbanyak pada penelitian ini yaitu stadium IIB dan IIIB yang merupakan kanker stadium lanjut. Hal ini sejalan dengan hasil dari beberapa penelitian di Indonesia yang menyatakan bahwa stadium kanker terbanyak adalah stadium II dan III, akan tetapi bertentangan dengan hasil penelitian di Polandia yang menemukan bahwa stadium kanker terbanyak adalah stadium awal (IAIIA) yaitu 74,5\%. ${ }^{13-16} \mathrm{Hal}$ ini kemungkinan karena pada umumnya masyarakat Indonesia masih belum memahami upaya pencegahan dan deteksi dini kanker serviks, sebagaimana diperlihatkan oleh penelitian Kusumawati et al. (2016) bahwa $62,5 \%$ pasien kanker serviks belum pernah melakukan pemeriksaan pap 
Tabel 4 Efek Samping Terapi

\begin{tabular}{|c|c|c|c|c|c|c|c|c|}
\hline \multirow{2}{*}{ Variabel } & \multicolumn{2}{|c|}{$2015(n=80)$} & \multicolumn{2}{|c|}{$2016(n=76)$} & \multicolumn{2}{|c|}{$2017(n=78)$} & \multicolumn{2}{|c|}{ Total $(n=234)$} \\
\hline & Jumlah & $\%$ & Jumlah & $\%$ & Jumlah & $\%$ & Jumlah & $\%$ \\
\hline Berdasarkan Jumlah & erjadi & & & & & & & \\
\hline $\begin{array}{l}\text { Semua Terapi } \\
\text { Tidak terjadi ES } \\
\text { Terjadi } 1 \text { jenis ES } \\
\text { Terjadi } 2 \text { jenis ES } \\
\text { Terjadi } 3 \text { jenis ES } \\
\text { Terjadi }>3 \text { jenis ES }\end{array}$ & $\begin{array}{r}13 \\
28 \\
30 \\
8 \\
1\end{array}$ & $\begin{array}{r}16,3 \\
35,0 \\
37,5 \\
10,0 \\
1,3\end{array}$ & $\begin{array}{r}15 \\
30 \\
18 \\
12 \\
1\end{array}$ & $\begin{array}{r}19,7 \\
39,5 \\
23,7 \\
15,8 \\
1,3\end{array}$ & $\begin{array}{r}12 \\
20 \\
24 \\
14 \\
8\end{array}$ & $\begin{array}{l}15,4 \\
25,6 \\
30,8 \\
17,9 \\
10,3\end{array}$ & $\begin{array}{l}40 \\
78 \\
72 \\
34 \\
10\end{array}$ & $\begin{array}{r}17,1 \\
33,3 \\
30,8 \\
14,5 \\
4,3\end{array}$ \\
\hline $\begin{array}{l}\text { Kemoradiasi }(\mathbf{n}=\mathbf{1 0 9} \\
\text { Tidak terjadi ES } \\
\text { Terjadi } 1 \text { jenis ES } \\
\text { Terjadi } 2 \text { jenis ES } \\
\text { Terjadi } 3 \text { jenis ES } \\
\text { Terjadi }>3 \text { jenis ES }\end{array}$ & $\begin{array}{r}7 \\
19 \\
15 \\
3 \\
0\end{array}$ & $\begin{array}{r}15,9 \\
43,2 \\
34,1 \\
6,8 \\
0,0\end{array}$ & $\begin{array}{r}5 \\
17 \\
9 \\
5 \\
0\end{array}$ & $\begin{array}{r}13,9 \\
47,2 \\
25,0 \\
13,9 \\
0,0\end{array}$ & $\begin{array}{r}0 \\
11 \\
9 \\
5 \\
4\end{array}$ & $\begin{array}{r}0,0 \\
37,9 \\
31,0 \\
17,2 \\
13,7\end{array}$ & $\begin{array}{r}12 \\
47 \\
33 \\
13 \\
4\end{array}$ & $\begin{array}{r}11,0 \\
43,1 \\
30,3 \\
11,9 \\
3,7\end{array}$ \\
\hline $\begin{array}{l}\text { Radioterapi Saja (n } \\
\text { Tidak terjadi ES } \\
\text { Terjadi } 1 \text { jenis ES } \\
\text { Terjadi } 2 \text { jenis ES } \\
\text { Terjadi } 3 \text { jenis ES } \\
\text { Terjadi }>3 \text { jenis ES }\end{array}$ & $\begin{array}{r}6 \\
9 \\
15 \\
5 \\
1\end{array}$ & $\begin{array}{r}16,7 \\
25,0 \\
41,7 \\
13,9 \\
2,8\end{array}$ & $\begin{array}{r}10 \\
13 \\
9 \\
7 \\
1\end{array}$ & $\begin{array}{r}25,0 \\
32,5 \\
22,5 \\
17,5 \\
2,5\end{array}$ & $\begin{array}{r}12 \\
9 \\
15 \\
9 \\
4\end{array}$ & $\begin{array}{r}24,5 \\
18,4 \\
30,6 \\
18,4 \\
8,1\end{array}$ & $\begin{array}{r}28 \\
31 \\
39 \\
21 \\
6\end{array}$ & $\begin{array}{r}22,4 \\
24,8 \\
31,2 \\
16,8 \\
4,8\end{array}$ \\
\hline Berdasarkan Jenis Es & & & & & & & & \\
\hline $\begin{array}{l}\text { Semua Terapi } \\
\text { Diare } \\
\text { Sembelit } \\
\text { Mulas } \\
\text { Mual } \\
\text { Muntah } \\
\text { Sakit BAB } \\
\text { Sakit BAK } \\
\text { Lecet } \\
\text { Gatal } \\
\text { Lain-lain }\end{array}$ & $\begin{array}{r}16 \\
10 \\
8 \\
28 \\
1 \\
7 \\
17 \\
14 \\
7 \\
9\end{array}$ & $\begin{array}{r}20,0 \\
12,5 \\
10,5 \\
35,0 \\
1,3 \\
8,8 \\
21,3 \\
17,5 \\
8,8 \\
10,0\end{array}$ & $\begin{array}{r}23 \\
1 \\
12 \\
20 \\
3 \\
4 \\
11 \\
13 \\
12 \\
10\end{array}$ & $\begin{array}{r}30,0 \\
1,3 \\
15,8 \\
26,3 \\
3,9 \\
5,3 \\
14,5 \\
17,1 \\
15,8 \\
9,3\end{array}$ & $\begin{array}{r}25 \\
8 \\
16 \\
38 \\
11 \\
3 \\
6 \\
8 \\
9 \\
14\end{array}$ & $\begin{array}{r}32,9 \\
10,5 \\
21,1 \\
50,0 \\
14,5 \\
3,9 \\
7,9 \\
10,5 \\
11,8 \\
18,4\end{array}$ & $\begin{array}{l}64 \\
19 \\
36 \\
86 \\
15 \\
14 \\
34 \\
35 \\
28 \\
33\end{array}$ & $\begin{array}{r}27,4 \\
8,1 \\
15,4 \\
36,8 \\
6,4 \\
6,0 \\
14,5 \\
15,0 \\
12,0 \\
14,1\end{array}$ \\
\hline $\begin{array}{l}\text { Kemoradiasi } \\
\text { Diare } \\
\text { Sembelit } \\
\text { Mulas } \\
\text { Mual } \\
\text { Muntah } \\
\text { Sakit BAB } \\
\text { Sakit BAK } \\
\text { Lecet } \\
\text { Gatal } \\
\text { Lain-lain }\end{array}$ & $\begin{array}{r}8 \\
3 \\
3 \\
12 \\
0 \\
5 \\
9 \\
8 \\
3 \\
7\end{array}$ & $\begin{array}{r}18,2 \\
6,8 \\
6,8 \\
27,3 \\
0,0 \\
11,4 \\
20,5 \\
18,2 \\
6,8 \\
15,9\end{array}$ & $\begin{array}{r}7 \\
1 \\
7 \\
13 \\
1 \\
1 \\
5 \\
6 \\
6 \\
2\end{array}$ & $\begin{array}{r}19,4 \\
2,8 \\
19,4 \\
36,1 \\
2,8 \\
2,8 \\
13,9 \\
16,7 \\
16,7 \\
5,6\end{array}$ & $\begin{array}{r}8 \\
8 \\
4 \\
20 \\
8 \\
0 \\
3 \\
4 \\
2 \\
4\end{array}$ & $\begin{array}{r}27,6 \\
27,6 \\
13,8 \\
69,0 \\
27,6 \\
0,0 \\
10,3 \\
13,8 \\
6,9 \\
13,8\end{array}$ & $\begin{array}{r}23 \\
12 \\
14 \\
45 \\
9 \\
6 \\
17 \\
18 \\
13 \\
13\end{array}$ & $\begin{array}{r}21,1 \\
11,0 \\
12,8 \\
41,3 \\
8,3 \\
5,5 \\
15,6 \\
16,5 \\
11,9 \\
11,9\end{array}$ \\
\hline $\begin{array}{l}\text { Radioterapi Saja } \\
\text { Diare } \\
\text { Sembelit } \\
\text { Mulas } \\
\text { Mual } \\
\text { Muntah } \\
\text { Sakit BAB } \\
\text { Sakit BAK } \\
\text { Lecet } \\
\text { Gatal } \\
\text { Lain-lain }\end{array}$ & $\begin{array}{r}8 \\
7 \\
5 \\
16 \\
1 \\
2 \\
8 \\
6 \\
4 \\
1\end{array}$ & $\begin{array}{r}22,2 \\
19,4 \\
13,9 \\
44,4 \\
2,8 \\
5,6 \\
22,2 \\
16,7 \\
11,1 \\
2,8\end{array}$ & $\begin{array}{r}16 \\
0 \\
5 \\
7 \\
2 \\
3 \\
6 \\
7 \\
6 \\
4\end{array}$ & $\begin{array}{r}40,0 \\
0,0 \\
12,5 \\
17,5 \\
5,0 \\
7,5 \\
15,0 \\
17,5 \\
15,0 \\
10,0\end{array}$ & $\begin{array}{r}18 \\
2 \\
12 \\
20 \\
3 \\
3 \\
3 \\
4 \\
7 \\
11\end{array}$ & $\begin{array}{r}30,0 \\
3,3 \\
20,0 \\
33,3 \\
5,0 \\
5,0 \\
5,0 \\
6,7 \\
11,7 \\
22,4\end{array}$ & $\begin{array}{r}42 \\
9 \\
22 \\
43 \\
6 \\
8 \\
17 \\
17 \\
17 \\
16\end{array}$ & $\begin{array}{r}33,6 \\
7,2 \\
17,6 \\
34,4 \\
4,8 \\
6,4 \\
13,6 \\
13,6 \\
13,6 \\
12,8\end{array}$ \\
\hline
\end{tabular}


smear yang merupakan pemeriksaan deteksi dini kanker serviks melalui pemeriksaan mikroskopis sel yang diambil dari serviks uterus, serta $100 \%$ belum pernah melakukan vaksinasi Human Papilomavirus (HPV). ${ }^{17}$ Sampai tahun 2017, cakupan program deteksi dini kanker serviks baru mencapai 1,01\% di Jawa Barat dan 2,98\% di Indonesia. ${ }^{18}$

Sesuai Pedoman Nasional Pelayanan Kedokteran (PNPK) tentang kanker serviks, penatalaksanaan kanker serviks pada stadium IIB-IIIB dilakukan dengan cara kemoradiasi atau dengan terapi radiasi tunggal (radioterapi). Penelitian oleh Li et al. (2014) menyatakan bahwa terapi dengan kemoradiasi pada pasien kanker serviks stadium lokal lanjut lebih efektif dan dapat ditoleransi dengan lebih baik dibandingkan dengan terapi menggunakan radioterapi saja. ${ }^{19}$ Pada penemuan penelitian ini, pasien kanker serviks di RSHS lebih banyak diberikan terapi dengan radiasi saja (radioterapi). Hal ini disebabkan oleh faktor medis maupun nonmedis. Salah satu contoh faktor medis adalah kondisi pasien yang tidak memungkinkan mendapat kemoterapi, sedangkan contoh faktor nonmedis adalah pasien yang tidak mau mendapat kemoterapi karena berbagai alasan, seperti takut dengan efek samping yang akan terjadi, atau pasien bersedia diberikan kemoterapi namun ruangan tidak tersedia.

Rata-rata waktu tunggu yang diperlukan pasien sejak pasien terdaftar sampai terapi pertama pada penelitian ini adalah sekitar 7 minggu, bahkan ada pasien yang menunggu mendapatkan terapi lebih dari 12 minggu. Lamanya waktu tunggu terapi ini disebabkan oleh adanya keterbatasan pesawat radiasi yang ada di RSHS. Saat ini pesawat yang tersedia hanya tiga buah, yaitu 1 buah pesawat Cobalt-60, 1 buah pesawat Linac, dan 1 buah pesawat Brakhiterapi. Waktu tunggu yang lebih lama untuk terapi dikhawatirkan dapat mengakibatkan perburukan penyakit seperti membesarnya ukuran tumor, serta memungkinkan untuk terjadi metastasis. Namun, RSHS telah berusaha sebaik mungkin dalam memberikan pelayanan kepada pasien. Hal ini dapat dilihat dari berkurangnya waktu tunggu pasien secara signifikan di tahun 2017 terhadap tahun 2015 dan 2016 ( $\mathrm{p}=0,000)$.

Pada penatalaksanaan kanker serviks dengan kemoradiasi, pasien diberikan dosis kecil sisplatin atau karboplatin sebagai radiosensitizer dengan tujuan memperkuat efek radiasi dan mengurangi metastasis. Dosis lazim yang diberikan adalah $40 \mathrm{mg} / \mathrm{m}^{2}$ setiap minggu dan diberikan di antara pemberian radioterapi ${ }^{20}$ Rata-rata dosis sisplatin yang diberikan setiap kali pemberian kemoterapi adalah 63,5 mg, dosis ini ada dalam rentang dosis yang dianjurkan sesuai dengan pedoman tatalaksana yang menetapkan dosis maksimal sebesar $76 \mathrm{mg},{ }^{21}$ karena pemberian dosis regimen kemoterapi pada tiap pasien kanker serviks berbeda sehingga harus disesuaikan berdasarkan luas permukaan tubuh pasien.

Mual dan diare merupakan efek samping yang paling sering terjadi pada pasien kanker serviks selama menjalankan terapi di RSHS. Hal ini sejalan dengan penelitian Enblom et al. (2009) yang menemukan bahwa mual dialami oleh $39 \%$ pasien yang menjalani radioterapi dan penelitian Maranzano et al. (2009) yang menemukan bahwa $27,1 \%$ pasien radioterapi mengalami mual. Pada hasil penelitian oleh Enblom et al., dilaporkan bahwa radioterapi pada bagian perut/pelvis berisiko lebih tinggi untuk mengalami mual (66\%) dibandingkan dengan radioterapi pada area lain, misalnya pada leher dan kepala (48\%). ${ }^{22-24}$ Pengobatan mual diberikan dengan berdasarkan pada risiko terjadinya mual, pada risiko tinggi atau sedang diberikan antagonis reseptor 5-HT3, seperti ondansetron dan granisetron ditambah dengan kortikosteroid seperti deksametason. ${ }^{25,26}$ Diare merupakan efek samping yang paling sering terjadi baik pada pasien yang diterapi dengan kemoradiasi atau radioterapi tunggal. Hal ini karena kedua terapi tersebut dapat 
memengaruhi sel sehat yang ada pada mukosa usus yang kemudian menyebabkan absorpsi cairan di usus terganggu sehingga akhirnya terjadi diare. Kerusakan mukosa usus juga mengakibatkan terganggunya penyerapan garam empedu, mempercepat peristaltik usus, serta mempercepat gerakan cairan dan feses yang ada di usus. Radiasi diketahui dapat menyebabkan gangguan pada mikro-ekologi, perubahan flora usus dan homeostasis inang yang dapat mengakibatkan proses apoptosis epitel usus. ${ }^{27}$ Diare akibat radiasi maupun kemoterapi bisa dicegah dengan pemberian obat antidiare atau pemberian probiotik. Penggunaan probiotik signifikan menurunkan insiden diare akibat radiasi, tetapi tidak ada perbedaan efek yang signifikan dengan obat antidare terhadap bentuk feses. ${ }^{27,28}$

Penelitian ini merupakan sebuah penelitian pendahuluan yang memberikan gambaran profil penatalaksanaan kanker serviks yang diberikan terapi radiasi dan kemoradiasi, oleh karena itu, penelitian ini mempunyai keterbatasan pada analisis data yang hanya dilakukan secara deskriptif. Perlu dilakukan analisis lebih lanjut seperti analisis efektivitas biaya untuk mengidentifikasi terapi mana yang lebih baik dalam hal efektivitas terapi dan biaya.

\section{Simpulan}

Terapi radiasi atau radioterapi merupakan terapi yang lebih banyak diberikan pada pasien kanker serviks stadium IIB-IIIB di Rumah Sakit Dr. Hasan Sadikin Bandung dengan dosis total sekitar 6700-7200cGy dan rata-rata lama terapi selama 14 minggu. Waktu tunggu yang dibutuhkan pasien untuk mendapat terapi rata-rata sekitar 7 minggu setelah mendaftar. Regimen kemoterapi yang paling sering digunakan sebagai radiosensitizer pada kemoradiasi adalah sisplatin dengan frekuensi pemberian 1-5 kali. Efek samping utama pada terapi kanker serviks baik dengan radioterapi maupun kemoradiasi adalah mual dan muntah. Analisis lebih lanjut diperlukan untuk mengetahui terapi mana yang lebih baik dari segi efektivitas terapi dan efektivitas biaya.

\section{Pendanaan}

Penelitian ini mendapat bantuan dana dari Badan Pengembangan dan Pemberdayaan Sumber Daya Manusia (PPSDM), Kementerian Kesehatan Republik Indonesia, dalam bentuk beasiswa pendidikan.

\section{Konflik Kepentingan}

Seluruh penulis menyatakan tidak terdapat potensi konflik kepentingan dengan penelitian, kepenulisan (authorship), dan atau publikasi artikel ini.

\section{Daftar Pustaka}

1. Kementerian Kesehatan Republik Indonesia. Pedoman nasional pelayanan kedokteran kanker serviks. Jakarta; Kementerian Kesehatan Republik Indonesia; 2017.

2. Bray F, Ferlay J, Soerjomataram I, Siegel RL, Torre LA, Jemal A. Global cancer statistics 2018: GLOBOCAN estimates of incidence and mortality worldwide for 36 cancers in 185 countries. CA Cancer J Clin. 2018;68(6):394-424. doi: 10.3322/ caac. 21492

3. Kementerian Kesehatan Republik Indonesia. Situasi penyakit kanker. Jakarta: Kementerian Kesehatan Republik Indonesia; 2015.

4. Suwendar, Fudholi A, Andayani TM, Sastramihardja HS. Evaluasi outcome klinik regimen kemoterapi berbasis cisplatin terhadap pasien kanker serviks. Prosiding Seminar Nasional Penelitian dan Pengabdian pada Masyarakat: Kesehatan; 
2016 Oktober 26-27; Bandung, Indonesia. Indonesia: Universitas Islam Bandung; 2016.

5. American Cancer Society. Treatment options for cervical cancer, by stage. [diunduh 17 Juni 2019]. Tersedia dari: https://www.cancer.org/cancer/cervicalcancer/treating/by-stage.html

6. Ryan TP. Sample size determination and power. Hoboken: John Wiley \& Sons, Inc; 2013. doi: 10.1002/9781118439241

7. Sharma P, Pattanshetty SM. A study on risk factors of cervical cancer among patients attending a tertiary care hospital: A case-control study. Clin Epidemiol Glob Heal. 2018;6(2):83-7. doi: 10.1016/j.ceg h.2017.10.001

8. Reis N, Beji NK, Kilic D. Risk factors for cervical cancer: Results from a hospitalbased case-control study. Int J Hematol Oncol. 2011;21(3):153-9. doi: 10.4999/u hod.09061

9. Franceschi S, Plummer M, Clifford G, de Sanjose S, Bosch X, Herrero R, et al. Differences in the risk of cervical cancer and human papillomavirus infection by education level. Br J Cancer. 2009;101(5): 865-70. doi: 10.1038/sj.bjc.6605224

10. Segni MT, Demissie HF, Tadesse DM, Amdemichael R, Mamo YT, Worku A. Level of knowledge and associated factor toward cervical cancer among women age (21-64) years visiting health facilities in gulele sub-city Addis Ababa Ethiopia. J Pancreas. 2017;18(1):44-8.

11. Kurniawati L, Nurrochmah S, Katmawanti S. Hubungan antara tingkat pendidikan, status pekerjaan dan tingkat pendapatan dengan usia perkawinan pertama wanita di Kelurahan Kotalama Kecamatan Kedungkandang Kota Malang. Prev Indones J Public Heal. 2017;1(2):1-10.

12. Chandrawati R. Faktor risiko yang berpengaruh dengan kejadian kanker serviks di RSUD dr. H. Abdul Moeloek
Provinsi Lampung. J Kesehat. 2016;7(2): 282-7. doi: 10.26630/jk.v7i2.202

13. Mukharomah KI, Cahyati WH. Diagnosis penderita kanker leher rahim di RSUD Kota Semarang. Public Heal Perspect J. 2016;1(1):60-6.

14. Dwipoyono B, Nasdaldy, Soemanadi, Sjamsuddin S, Adisasmita AC. Jenis histologik dan umur pada kanker serviks uteri di Rumah Sakit Kanker "Dharmais". Indones J Cancer. 2007;1(1):7-11.

15. Watulingas AM, Loho M, Wagey F. Karakteristik penderita kanker serviks di RSUP Prof. Dr. R. D. Kandou Manado periode 1 Januari 2013-31 Desember 2015. J e-Clinic. 2016;4(2):2-6. doi: 10.35790/ ec 1.4.2.2016.14477

16. Nowakowski A, Cybulski M, Buda I, Janosz I, Olszak-Wasik K, Bodzek P, et al. Cervical cancer histology, staging and survival before and after implementation of organised cervical screening programme in Poland. PLoS One. 2016; 11(5): e0155849. doi: 10.1371/journal.pone .015 5849

17. Kusumawati Y, Nugrahaningtyas RW, Rahmawati EN. Pengetahuan, deteksi dini dan vaksinasi HPV sebagai faktor pencegah kanker serviks di Kabupaten Sukoharjo. J Kesehat Masy. 2016;11(2):204-13. doi: 10. 15294/kemas.v11i2.4208

18. Kementerian Kesehatan Republik Indonesia. Profil kesehatan Indonesia tahun 2017. Jakarta: Kementerian Kesehatan Republik Indonesia; 2017.

19. Li Z, Yang S, Liu L, Han S. A comparison of concurrent chemoradiotherapy and radiotherapy in Chinese patients with locally advanced cervical carcinoma: A multi-center study. Radiat Oncol. 2014; 9:212. doi: 10.1186/1748-717X-9-212

20. Vordermark D. Radiotherapy of cervical cancer. Oncol Res Treat. 2016;39(9):51620. doi: $10.1159 / 000448902$

21. National Health Servic South East London Cancer Network. Weekly cisplatin 
plus radiotherapy for locally advanced cervical/vaginal/vulval cancer [diunduh 28 Agustus 2019]. Tersedia dari: http:// www.londoncanceralliance.nhs.uk/medi a/41617/Gynae_Cervix_Vagina_Vulva_ Cisplatin-40plus RT_protocol_V2.0.pdf

22. Enblom A, Bergius Axelsson B, Steineck G, Hammar M, Börjeson S. One third of patients with radiotherapy-induced nausea consider their antiemetic treatment insufficient. Support Care Cancer. 2009; 17 (1):23-32. doi: 10.1007/s00520-008-0445 $-\mathrm{x}$

23. Maranzano E, De Angelis V, Pergolizzi S, Lupattelli M, Frata P, Spagnesi S, et al. A prospective observational trial on emesis in radiotherapy: Analysis of 1020 patients recruited in 45 Italian radiation oncology centres. Radiother Oncol. 2010;94(1):3641. doi:10.1016/j.radonc.2009.11.001

24. Dennis K, Maranzano E, Angelis C De, Holden L, Wong S, Chow E. Radiotherapyinduced nausea and vomiting. Expert Rev Pharmacoeconomics Outcomes Res.
2011;11(6):685-92. doi: 10.1586/erp.11.77. 25. Feyer P, Jahn F, Jordan K. Radiation induced nausea and vomiting. Eur J Pharmacol. 2014;722:165-71. doi: 10.10 16/j.ejphar.2013.09.069

26. Feyer PC, Maranzano E, Molassiotis A, Roila F, Clark-Snow RA, Jordan K. Radiotherapy-induced nausea and vomiting (RINV): MASCC/ESMO guideline for antiemetics in radiotherapy: Update 2009: Support Care Cancer. 2011;19(1):5-14. doi: 10.1007/s00520-010-95 0-6

27. Liu MM, Li ST, Shu Y, Zhan HQ. Probiotics for prevention of radiationinduced diarrhea: A meta-analysis of randomized controlled trials. PLoS One. 2017;12(6):1-15. doi: 10.1371/journal.po ne. 0178870

28. Demers M, Dagnault A, Desjardins J. A randomized double-blind controlled trial: Impact of probiotics on diarrhea in patients treated with pelvic radiation. Clin Nutr. 2014;33(5):761-7. doi: 10.1016/j.cl nu.2013.10.015 